\title{
Armored catfish (Siluriformes: Loricariidae) from the Miocene of southern Pampas and its palaeobiogeographical implications
}

\author{
Sergio Bogan ${ }^{1} \cdot$ Federico Agnolin ${ }^{1,2}$
}

Received: 27 May 2019/Accepted: 11 July 2019/Published online: 29 July 2019

(C) Akademie der Naturwissenschaften Schweiz (SCNAT) 2019

\begin{abstract}
Armored catfishes are grouped within the clade Loricariidae. They are typically Brazilian freshwater fishes that show a high taxonomic diversity in South America and are distributed from Costa Rica to Buenos Aires province, Argentina. The aim of the present contribution is to describe an isolated pectoral spine of a loricariid coming from Late Miocene beds of southern Pampas, at Buenos Aires province, Argentina. This record constitutes the first finding of a fish in the Chasicó area, Arenas Blancas fossiliferous site, and is located far from the current geographical range of loricariids. The finding of a loricariid is congruent with the idea of a warm climate and the possibility that southern paleobasins of Pampas and northern Patagonia were hydrographically connected with paleobasins that hold Brazilian freshwater fishes.
\end{abstract}

Keywords Loricariidae · Chasicó · Palaeobiogeography · Pectoral spine

\section{Introduction}

Siluriform catfishes of the clade Loricarioidea include six neotropical families: Trichomycteridae, Nematogenyiidae, Callichthyidae, Scoloplacidae, Astroblepidae, and Loricariidae with more than 1200 described species (Nelson et al. 2016; Ferraris 2007).

Loricariids are geographically distributed from Costa Rica and Panamá to Argentina (López and Miquelarena 1991) up to the Salado River basin at Buenos Aires province (Ringuelet 1975). They include approximately 96 genera and 716 species (Ferraris 2007) that are grouped in

Editorial Handling: D. Marty.

Sergio Bogan

sergiobogan@yahoo.com.ar

Federico Agnolin

fedeagnolin@yahoo.com.ar

1 Fundación de Historia Natural "Félix de Azara", Departamento de Ciencias Naturales y Antropología, Universidad Maimónides, Hidalgo 775 piso 7 , C1405BDB Buenos Aires, Argentina

2 Laboratorio de Anatomía Comparada y Evolución de los Vertebrados, Museo Argentino de Ciencias Naturales "Bernardino Rivadavia", Av. Ángel Gallardo, 470, C1405DJR Buenos Aires, Argentina five different subfamilies: Ancistrinae, Hypoptopomatinae, Hypostominae, Loricariinae, and Lithogeninae.

Loricariids are benthonic fishes that exhibit several rows of dermal plates, as well as abundant odontodes (denticles) along their entire body, distributed even on the fins. The mouth is ventrally located, and modified lips are used to feed, breathe, and attach to the substrate (Armbruster 2004).

In South America, the fossil record of loricariids is mainly represented by isolated materials of low taxonomic value (Ferraris 2007; Lundberg 1998; Malabarba 1988; Cione et al. 2005). However, Malabarba and Lundberg (2007) described from the Oligocene of Brazil the new genus and species Taubateia paraiba, which constitutes the oldest undoubted record for the clade. Cione et al. (2005) described from the Late Miocene of Patagonia, fossil bones referred to Loricariidae. This record was striking, because it was located more than $500 \mathrm{~km}$ southward of the extant southernmost range of the family.

The aim of the present contribution is to describe an isolated pectoral spine of a loricariid coming from Late Miocene beds of southern Pampas, at Buenos Aires province, Argentina. This record constitutes not only the first finding of a fish from this fossil area, but also is located outside the current geographical range of Loricariidae. On this basis, the fossil record of the clade is discussed and analyzed. 


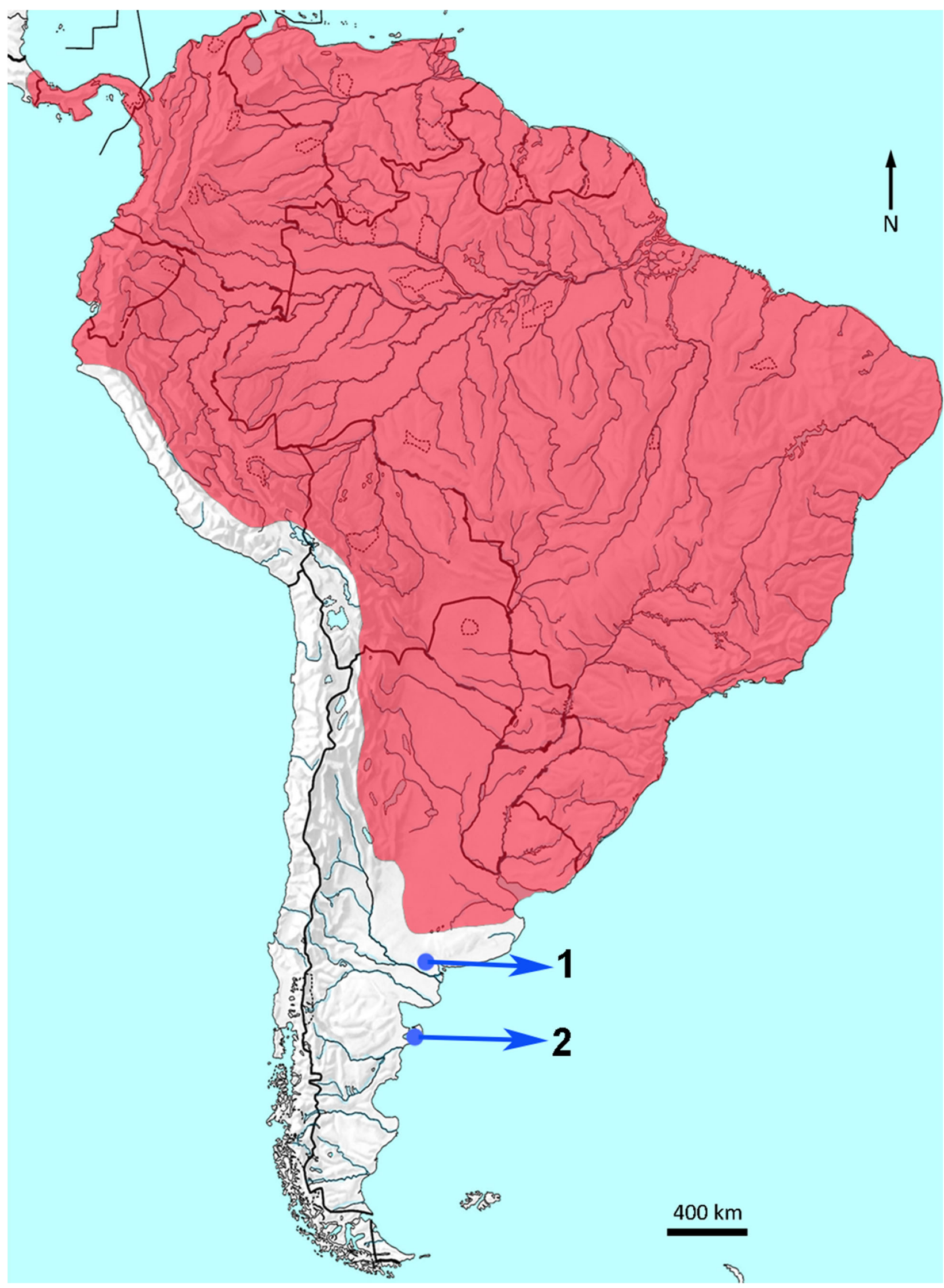


4Fig. 1 Geographical distribution of the clade Loricariidae (shaded) indicating fossil sites that are far from the extant distribution of the family. 1: "Arenas Blancas", Arroyo Chasicó, Buenos Aires province, Argentina; 2: Puerto Madryn Formation (Upper Miocene) at Punta Delgada site, Chubut province, Argentina

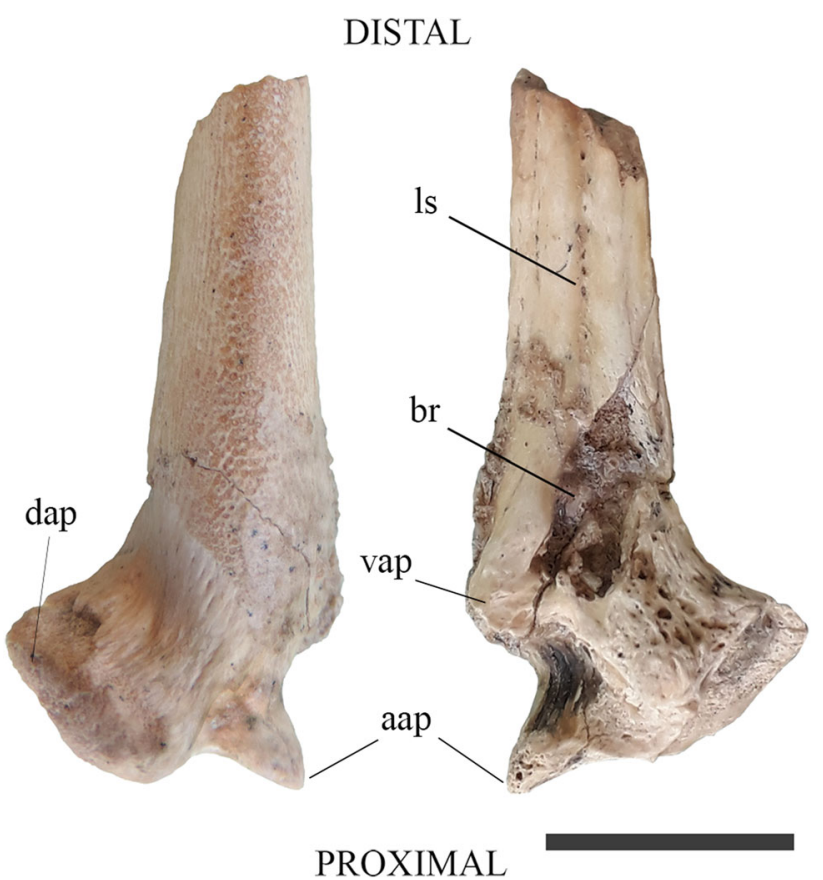

Fig. 2 Indeterminate Loricariidae (MMH-CH-85-4-140), left pectoral spine in: a anterior; and $\mathbf{b}$ posterior views. aap anterior articular process, $b r$ basal recess, dap dorsal articular process, $l s$ longitudinal sulcus, vap ventral articular process. Scale bar equals $10 \mathrm{~mm}$

\section{Geological and geographical context}

The specimen here described was found in paleontological collections at the Museo Municipal "Vicente Di Martino" $(\mathrm{MMH})$. The specimen has stratigraphical and geographical provenance. However, the specimen lacks a more detailed stratigraphical position.

The fossil specimen comes from "Arenas Blancas" fossil site $\left(38^{\circ} 34^{\prime} 25^{\prime \prime} \mathrm{S}-62^{\circ} 58^{\prime} 25^{\prime \prime} \mathrm{O}\right)$ which is located at the lower course of the Chasicó stream (Buenos Aires province), at approximately $9.5 \mathrm{~km}$ from its mouth in the Chasicó lagoon (Fig. 1; Oliva et al. 2011).

In "Arenas Blancas" site, the base of the stratigraphical column, mainly composed by sandy silt material and fangolites corresponding to the Arroyo Chasicó Formation (Upper Miocene) which is the stratotype of the Chasicoan SALMA (Pascual et al. 1965). Overlaying this unit, in erosive discordance, there are sandstones and conglomerates of fluvial origin. These deposits were considered by Tonni et al. (1998) as part of an innominate lithostratigraphic unit that is Huayquerian in age (Upper Miocene), being slightly younger than the above-mentioned Chasicoan SALMA (Zárate et al. 2007). Further, the mammalian fauna recovered at the same levels where the specimen here studied was found is typical of Chasicoan/ Huayquerian ages (Late Miocene; Oliva et al. 2011).

According to the available collection data, the specimen here described certainly belongs to an outcrop of the Late Miocene. Regrettably, it is not possible to refer the material to any of the above stratigraphical units.

Institutional abbreviations: MMH-CH, Colección Chasicó, Museo Municipal "Vicente Di Martino", Monte Hermoso, Buenos Aires province, Argentina.

\section{Systematic paleontology}

Order SILURIFORMES Grande, 1987

Suborder LORICARIOIDEI Grande, 1987

Family LORICARIIDAE Gill, 1872

Indeterminate genus and species

Referred material: MMH-CH-85-4-140, proximal end of a left pectoral spine (Fig. 2).

Description: The spine is incompletely preserved and lacks its distal portion. The spine is robust, well ossified, and gently curved. It shows a subcircular to subtriangular shape in cross section. The proximal end shows a well-developed dorsal process that is roughly crescent-shaped and has a smooth surface. The anterior process is acute and subtriangular in contour. The posterior process is badly damaged, but the preserved portion is relatively robust and is slightly protrudent from the main spine axis. Most of the spine shaft (especially the dorsal, anterior, and ventral surfaces) is covered with relatively prominent and abundant semicircular rings that represent the base for implantation of the odontodes. These rings are larger and are more prominent in the anterior surface of the spine. The neck of the spine is smooth, lacking any sign of odontode bases.

The dorsal and ventral surfaces show abundant subparallel longitudinal ridges and grooves, which show small odontode rings at their bottom.

The posterior surface shows a proximal articular concavity that is suboval in contour and is well delimited by the dorsal and ventral rami of the spine. Distal to this concavity there exists a well-defined longitudinal groove that is subparallel to the main axis of the spine. This groove lacks any sign of denticles or serrations and only shows some isolated foramina located at the bottom of the groove. 


\section{Discussion}

\section{Taxonomical referral of specimen MMH-CH-85-4- 140}

The specimen is referred to Siluriformes by having ossified pectoral spines with a well-defined and complex proximal end having a crescent-shaped dorsal process that articulates with the cleithrum. MMH-CH-85-4-140 is comfortably included within Loricariidae on the basis of the following combination of characters: relatively large and stout pectoral spines lacking denticles and serration on the posterior surface, and presence of abundant odontodes on the dorsal, anterior, and ventral surfaces (Lundberg 1997; Cione et al. 2005; Bogan et al. 2008, 2010). The morphology of MMHCH-85-4-140 is reminiscent to those of the Hypostominae clade in having large-sized spines that are suboval in cross section that are not strongly dorsoventrally compressed, and by having relatively large and well-developed odontode bases (Fig. 2; Bogan et al. 2008). However, because of the low taxonomical value of isolated pectoral spines, the referral of MMH-CH-85-4-140 among loricariids is far from certain.

\section{Palaeobiogeographical implications}

In spite of the high diversity and abundance of extant loricariids in South America, the fossil record of the group is patchy. In 1898, Florentino Ameghino (1898) was the first author to mention the presence of fossil loricariids coming from South America. He reported specimens from the Late Pleistocene of Buenos Aires province that he identified as belonging to the living species Plecostomus commersonii (a junior synonym of Hypostomus commersoni). Lately, hypostomines were repeatedly mentioned and described from different sites at the Buenos Aires and Santa Fe provinces, Argentina (Cione and López Arbarello 1995; Bogan et al. 2008, 2010; Vallone et al. 2017).

As mentioned above, the oldest record for loricariids comes from Late Oligocene-Early Miocene Tremembé Formation from Brazil, where indeterminated loricariids (Malabarba 1988) and Taubateia paraiba, of uncertain phylogenetic position among loricariids, have been described (Malabarba and Lundberg 2007).

Remains assigned to indeterminate Loricariidae were reported on the basis of isolated elements from Miocene deposits at La Venta, Colombia (Lundberg 1997), and loricariids were also mentioned and illustrated from the Late Miocene of Paraná, Argentina (Arratia and Cione 1996; Cione et al. 2013).

Cione et al. (2005) described diverse materials of undetermined loricariids from the Puerto Madryn
Formation (Late Miocene) at Punta Delgada site, in Chubut province, Patagonia, Argentina. This record was striking, because it was located more than $500 \mathrm{~km}$ southward of the extant southernmost range of the family (Fig. 2).

MMH-CH-85-4-140 constitutes a new addition to the knowledge of the past distribution of loricariids during the Miocene. Present report is intimately related to Cione et al. (2005) fossil report, being both findings of similar geological ages. As in the latter case, MMH-CH-85-4-140 is far south from the current distribution of the clade.

The Neotropical Region is traditionally divided into the Austral and Brazilian ichthyogeographic Subregions (Ringuelet 1975; Menni 2004). Most of the diversity of freshwater fishes is restricted to the Brazilian Subregion, the area to which loricariid catfishes are now confined (Ringuelet 1975; Almirón et al. 1997). In this way, loricariids are disseminated along tropical and subtropical climates, strongly diminishing its diversity southward (Vari and Malabarba 1998). The southernmost loricariid record is at the Salado Basin at Buenos Aires province (Ringuelet 1975; López and Miquelarena 1991; Bertora et al. 2018), a geographical area that constitutes the southernmost limit of several freshwater Brazilian fish clades that are sensitive to low temperatures, as is the case of loricariids (Fig. 2; Ringuelet 1961).

The presence of loricariids and pimelodids at northern Patagonia by Late Miocene times was regarded by Cione et al. $(2005,2013)$ as indicative of warm climatic condition (see Naish et al. 2001). Present finding of a loricariid in the Neogene of southern Buenos Aires province is congruent with the hypothesis envisaged by Cione et al. (2005) suggesting a more widespread geographical distribution of Brazilian fishes.

In contrast, the fossil record of loricariids in the Pampean Region during the Quaternary is restricted to the northern half of the province, well within the range of the current distribution of the family (Bogan et al. 2010). In this sense, the rich fossiliferous sites located South to the Salado Basin (e.g., Centinela del Mar, Bajo San José, Quequén Salado; Deschamps and Borromei 1992; Bogan et al. 2009a, b, 2012) do not yielded fossil loricariids, which is congruent with the current distribution of the clade.

The study area is near the boundary of a NW-SE elongated topographic depression within the Colorado sedimentary basin (Zárate et al. 2007). In this region, faults follow NW-SE, E-W, and NE-SW trends (Bonorino et al. 1987). This is in agreement with González Uriarte (1984), whom mentioned that during the Miocene the estuary of Bahía Blanca may have acted as a paleo-runoff of waters, which probably extended along the Chasicó-Salinas Chicas-Salitral de la Vidriera-Canal Principal depression; its 
drainage contributing to the deposition of Chasicó sediments (Giagante 2009).

The finding of a fluvial paleochannel at the bottom of Bahia Blanca estuary that was contemporary to Chasicó deposits constitutes an additional prove of the existence of an ancient NW-SE drainage system (Giagante 2009). Further, the presence and development of such paleochannel indicates that it corresponded with a much lower average sea level than today. In this way, with a sea that was far away, there was a predominance of fluvial and eolic sediments, determining a paleoenvironment that was driven by continental influence (Zárate et al. 2007; Giagante 2009).

As indicated above, during the Miocene the "Arenas Blancas" deposits have an important fluvial influence that is correlated with a NW-SE drainage system that extended along the Chasicó-Salinas Chicas-Salitral de la VidrieraCanal Principal depression, being part of the Colorado paleobasin (Zárate et al. 2007; Giagante 2009). Currently, the Colorado river lacks of loricariid species (Almirón et al. 1997; Menni 2004). However, this basin presents a mixed species assemblage, including the southernmost records of Brazilian fishes together with Austral taxa (Almirón et al. 1997). This probably constitutes a relictual ichthyological assemblage, reflecting the ancient connections between Patagonian and northern hydrographic basins.

In this sense, Cione et al. (2005) hypothesized the rivers of northern Patagonia during the Late Miocene were hydrographically connected with more northern basins at some point. This explained the presence of Brazilian fishes on northern Patagonia by late Neogene times. In spite of the still poor record of "Arenas Blancas" fishes, the finding of a loricariid is congruent with the idea indicating that these southern paleobasins were hydrographically connected with paleobasins that hold Brazilian freshwater fishes.

Acknowledgements Special thanks to R. Tomassini (Universidad Nacional del Sur) for his help during the development of present MS, as well as for sending important information about the specimen MMH-CH-85-4-140. We also thank Natalia Sánchez (MMH) for help and advice. We thank Adrián Giacchino (Fundación de Historia Natural "Félix de Azara", Universidad Maimónides) for his constant support.

\section{References}

Almirón, A., Azpelicueta, M., Casciotta, J., \& López, Cazorla A. (1997). Ichthyogeographic boundary between the Brazilian and Austral subregions in South America, Argentina. Biogeographica, 73, 23-30.

Ameghino, F. (1898). Sinopsis geologíco-paleontológica de la Argentina. Segundo Censo Nac Repúb Argentina, Territ, 1, $115-228$
Armbruster, J. W. (2004). Phylogenetic relationships of the suckermouth armoured catfishes (Loricariidae) with emphasis on the Hypostominae and the Ancistrinae. Zool J Linn Soc, 141(1), $1-80$.

Arratia, G., \& Cione, A. (1996). The record of fossil fishes of southern South America. Müncher Geowiss Abh Reihe A. Geol Paläontol, 30, 9-72.

Bertora, A., Grosman, F., Sanzano, P., Cardoso, Y. P., \& Rosso, J. J. (2018). Taxonomic revision of the Southernmost population of Hypostomus commersoni Valenciennes, 1836 (Siluriformes: Loricariidae) and comments on dispersal routes. Hist Nat, 8(1), 25-34.

Bogan, S., Agnolin, F. L., Oliva, C., \& Campmourteres, V. (2012). Nuevas consideraciones sobre una asociación ictiofaunística del Pleistoceno Tardío del río Quequén Salado, provincia de Buenos Aires, Argentina. Stud Geol Salmant, 48, 89-127.

Bogan, S., Agnolin, F., \& Ramírez, J. L. (2010). Ictiofauna y herpetofauna del Pleistoceno Superior continental de la localidad de Salto, provincia de Buenos Aires, Argentina. Stud Geol Salmant, 46, 83-97.

Bogan, S., de los Reyes, M. L., \& Cenizo, M. M. (2009a). Primer registro del género Jenynsia Günther, 1866 (Teleostei: Cyprinodontiformes) en el Pleistoceno Medio tardío de la provincia de Buenos Aires (Argentina). Pap Avulsos Zool, 49(5), 81-86.

Bogan, S., de los Reyes, M. L., \& Cenizo, M. (2009b). Primeros registros fósiles de pejerreyes (Teleostei: Atheriniformes) en el Pleistoceno Medio de la provincia de Buenos Aires, Argentina. Rev Mus Argent Cienc Nat, 11(2), 185-192.

Bogan, S., de los Reyes, M. L., Toledo, M. J., \& Ramírez, J. L. (2008). Registros fósiles de "viejas del agua" (Teleostei: Siluriformes) del Pleistoceno superior de la localidad de Salto, Buenos Aires, Argentina. Stud Geol Salmant, 44, 203-212.

Bonorino, A. G., Kostadinoff, J., \& Schillizzi, R. (1987). Geofísica y geología del sector noroccidental de la cuenca del Colorado, provincia de Buenos Aires. Geoacta, 17, 167-177.

Cione, A. L., Azpelicueta, M. M., Casciotta, J. R., \& Dozo, M. T. (2005). Tropical freshwater teleosts from Miocene beds of eastern Patagonia, southern Argentina. Geobios, 38, 29-42.

Cione, A. L., Cabrera, D. A., Azpelicueta, M. M., Casciotta, J. R., \& Barla, M. J. (2013). Peces del Mioceno marino y continental en Entre Ríos, Oriente central de Argentina. Publ Electr Asoc Paleontol Argentina, 14(1), 71-84.

Cione, A. L., \& López Arbarello, A. (1995). Los peces de agua dulce fósiles del área pampeana. Evol Biol Clim Reg Pampeana Durante Últim Cinco Millones de Años, Monogr Museo Nac Cienc Nat Madrid, 12, 131-142.

Deschamps, C. M., \& Borromei, A. M. (1992). La fauna de vertebrados pleistocénicos del Bajo San José (provincia de Buenos Aires, Argentina). Aspectos paleoambientales. Ameghiniana, 29(2), 177-183.

Ferraris, C. J. (2007). Checklist of catfishes, recent and fossil (Osteichthyes: Siluriformes), and catalogue of siluriform primary types. Zootaxa, 1418, 1-628.

Giagante, D. A. 2009. Sismoestratigrafía marina del sector costero entre Bahía Blanca y Punta Alta, provincia de Buenos Aires. Unpublished $\mathrm{PhD}$ thesis, Universidad Nacional del Sur, Bahía Blanca.

González Uriarte, M. (1984). Características geomorfológicas de la porción continental que rodea la Bahía Blanca, Provincia de Buenos Aires. IX Congreso Geológico Argentino, Actas 3, Bariloche, Río Negro, Argentina.

López, H. L., \& Miquelarena, A. M. (1991). Los Hypostominae (Pisces: Loricariidae) de Argentina. In Z. A. Castellanos (Ed.), Fauna de Agua Dulce de la República Argentina (pp. 1-64). La Plata: Profadu-CONICET. 
Lundberg, J. (1997). Fishes of the La Venta fauna: additional taxa, biotic and paleoenviromental implications. In R. F. Kay, R. L. Madden, R. H. Cifelli, \& J. J. Flynn (Eds.), Vertebrate paleontology in the Neotropics: The Miocene fauna of La Venta (pp. 67-91). Washington DC: Smithsonian Institution Press.

Lundberg, J. G. (1998). The temporal context for the diversification of neotropical fishes. In L. R. Malabarba, R. E. Reis, R. P. Vari, Z. M. Lucena, \& C. A. S. Lucena (Eds.), Phylogeny and classification of neotropical fishes (pp. 519-536). Porto Alegre: Edipucrs.

Malabarba, M. C. S. L. (1988). Loricariid dermal plate and pectoral fin spines (Osteichthyes, Siluriformes). Comun Museo Ciênc PUCRS, Sér Zool, 5, 1-5.

Malabarba, M. C. S. L., \& Lundberg, J. G. (2007). A fossil loricariid catfish (Siluriformes: Loricarioidea) from the Taubaté Basin, eastern Brazil. Neotrop Ichthyol, 5(3), 263-270.

Menni, R. C. (2004). Peces y ambientes en la Argentina continental. Monogr Museo Argentino Cienc Nat, 5, 1-323.

Naish, T., Woolfe, K., Barrett, P., Wilson, G., Atkins, C., Bohaty, S., et al. (2001). Orbitally induced oscillations in the East Antarctic ice sheet at the Oligocene/Miocene boundary. Nature, 413, 719-723.

Nelson, J. S., Grande, T. C., \& Wilson, M. V. (2016). Fishes of the World. Hoboken: Wiley.

Oliva, C., Di Martino, V. \& Retamozo, M. (2011). Nuevos aportes al conocimiento del Piso/Edad Huayqueriense (Mioceno tardío) del curso inferior del Arroyo Chasicó. In: IV Congreso Latinoamericano de Paleontología de Vertebrados, San Juan province, Argentina.

Pascual, R., Ortega Hinojosa, J., Gondar, D., \& Tonni, E. (1965). Las edades del Cenozoico mamalífero de la Argentina, con especial atención a aquellas del territorio bonaerense. An Com Investig Cient Prov B Aires, 6, 165-193.

Ringuelet, R. A. (1961). Rasgos fundamentales de la zoogeografía de la Argentina. Physis, 22(63), 151-170.

Ringuelet, R. A. (1975). Zoogeografía y ecología de los peces de aguas continentales de la Argentina y consideraciones sobre las áreas ictiológicas de América del Sur. Ecosur, 2(3), 1-122.

Tonni, E.P., Scillato-Yané, G.J., Cione, A.L. \& Carlini, A.A. (1998) Bioestratigrafía del Mioceno continental en el curso inferior del arroyo Chasicó, provincia de Buenos Aires. In: VII Congreso Argentino de Paleontología y Bioestratigrafía, p 135.

Vallone, E. R., Vezzosi, R. I., \& Cione, A. L. (2017). First fossil fish (teleostei, siluriformes) from the late Pleistocene of Santa $\mathrm{Fe}$ Province, Argentina. Alcheringa, 41(3), 369-377.

Vari, R. P., \& Malabarba, L. R. (1998). Neotropical ichthyology: an overview. Phylogeny Classif Neotrop Fishes, 1, 1-12.

Zárate, M. A., Schultz, P. H., Blasi, A., Heil, C., King, J., \& Hames, W. (2007). Geology and geochronology of type Chasicoan (late Miocene) mammal-bearing deposits of Buenos Aires (Argentina). J S Am Earth Sci, 23(1), 81-90. 